\title{
Culture Communication: Is an Effective Support for Conflict Resolution and Peace Process in Myanmar?
}

\author{
Hsu Thiri Zaw ${ }^{1}$ \\ ${ }^{1}$ 3rd Year, Ph.D, School of Journalism and Information communication, Huazhong University of Science and Technology, \\ China
}

Correspondence: Hsu Thiri Zaw, 3rd Year, Ph.D, School of Journalism and Information communication, Huazhong University of Science and Technology, China.

Received: February 5, 2019

Accepted: February 23, $2019 \quad$ Available online: February 26, 2019

doi:10.11114/ijsss.v7i2.4095

URL: https://doi.org/10.11114/ijsss.v7i2.4095

\begin{abstract}
Culture is a system of shared belief and customs in the society. In other way, culture is the symbol of the life of people. Myanmar and its citizen has suffered the trauma of ethnic conflicts throughout the history since 1948. The governments of Myanmar throughout the times have also been finding the solution for conflict resolution and peace process based on the political approach. Now, it is the time for considering about an alternative approach to conflict resolution and peace process based on the culture which is the symbol of the people. The study aims to provide the new interpretation in completing conflict resolution by Myanmar government and a kind of support that can reveal the hidden and being forgotten cultures and identities of ethnic minority groups in Myanmar based on cultural communication. The researcher made two group discussions with ethnic people in two ethnic regions of Myanmar and had in-depth conversation for detailed facts and information. The research mainly presents the impact of culture communication as a better tool for conflict resolution and peace process based on the real voices of ethnic people.
\end{abstract}

Keywords: culture, culture communication, conflict resolution, peace process, Myanmar

\section{Introduction}

Republic of the Union of Myanmar lies between latitudes 10 degree and 28 degree north and longitudes 92 degree and 102 degree east of Greenwich and its total area is about 261228 square mile. According to geography situation, there are three main rivers in the country that are crossing from north to south. The Irrawaddy, the most famous and longest river in Myanmar is flowing from north through the heart of the country to the Andaman Sea which is so important for transportation and trading in Myanmar. From the Hukawng Valley, the Chindwin flows to the Irrawaddy in upper Myanmar area. The Salween which drains from central Tibet and flows through some regional countries to the sea enters into Myanmar in Shan state and it is also important in the history of people who are residing in hilly regions such as Kokangs, Was, Akhas, Lahus, Karens and Mons. Moreover, the Salween river is also popular for it political and military significance. (Tucker, 2001)

Moreover, Sittaung which is shorter and slower than other famous rivers, drains in the Karen region and Bago Yoma. Although it is not popular and important, it is such a remarkable river for Karen ethnic people. There are three seasons in Myanmar which are summer, monsoon and winter. During the monsoon, there are floods in most of the regions in the country especially the regions of the ethnic people. That also lead to the isolated lives of ethnic people from the plain area where majority Burmese people are living. When it is being said about the residents in Myanmar, it can be divided the people into three discrete language groups who were migrated into Myanmar territory since long time ago. (Tucker, 2001) They are the Mon-Khmers who include the Mons, Was, Palaungs and Padaungs; the second one is Tibeto-Burmans who are Burmans and Rakhines, Chins and Kachins, and the last one is T'ai- Chinese who are the Karens and the Shans. Lately, the people of Myanmar are divided into 8 major ethnic groups but the total sub ethnic groups are over 135 groups.

The political geography of Myanmar is complicated due to the diversity and cross-breeding on the ethnic people. The people settle down in different regions throughout the country, so the culture, tradition, language, beliefs, ideas and so on are totally differenct with each other. Followed by the ethnic and culture diversity in the country, political and ethnic tensions between majority groups and ethnic minority groups have become serious throughout the time. During the British colonial time in 1886, Myanmar was one of the Indian provinces and it was not a separate country. In 1947, the 
national independence hero, General Aung San and some leaders accomplished a national agreement by negotiating with the ethnic leaders and people for independence and persuaded ethnic people to enter into the umbrella of Union of Myanmar. He established the Panglong Agreement in February, 1947 that included his government promises to ethnic people for their rights. (Smith \& Ekeh, 2007)

However, the dream of General Aung San and national independence leaders destroyed with the revolution of Karen ethnic group in 1949 for their ethnic rights. Since from 1949, ethnic conflicts have always been nightmares of the government and local people of Myanmar. Those ethnic conflicts have been breaking out over 70 years in the country and there is no strong agreement for conflict resolution and peace in the country yet. The democratic government which took national power since 2011 initiated conflict resolution and peace process and the current government is also implanting the basic foundation and agreement on the peace process, however, there is no significant solution or result so far.

\section{Literature Review}

\subsection{Culture in Multicultural Society}

Culture is a system of shared beliefs and values which are learned rather than inherited. It is composed of those values and beliefs, norms, symbols and ideologies that make up the total way of life of a people. Culture has also been defined as a form of 'map' which each of us has implanted in us by the society into which we are born. This 'map' defines reality, sets the guidelines for behaviour, thus developing our value system, and establishes the rules for problem solving or explaining events that are not normally encountered.

Concerning about culture, Hofstede (1994) defined culture as: "The collective programming of the mind, which distinguishes the members of one group or category of people from another." He maintains that the 'software' of the mind distinguishes the members of one group of people from another. It is built up by the family environment, schooling, the influence of the neighbourhood, the social environment of the local community and the workplace. All these influences add to one's life experiences and become part of one's cultural background.

Gudykunst (2003) stated in Olajide (2017) and Phillip (2017) that cultural tradition is distinguished according to common geographical origin or descent from a small number of common ancestors, common literature, long history, common religion and so on. Based on diverse and distinct groups in a society, multiculturalism has emerged and become one of the most controversial intellectual and political concepts in democracies society yet. In this case cultural dimensions could be traced to individualism and collectivism factors in communication. Collectivism cultures significances are on community, shared interests, harmony, tradition, the public good, and maintain face. On the other hand, individualism features are characteristics traced to each member of the community. With the existence of cultural differences in society, many scholars discussed about multiculturalism and intercultural communication in cultural plural society.

Concerning culture, Hall (1976) differentiated between high context communications and cultures and low context communication and cultures as;

"A high context communication is one in which most of the information is either in the physical context or internalized in the person, while very little is in the coded, explicit, transmitted part of the message. A low context communication is just the opposite; the mass of the information is vested in the explicit code." (Hall, 1976)

Some scholars mention about high and low context culture based on language and linguistics codes. They pointed out that high context communications are mostly used when social relations are important while low context communications are used when social relationships are not so important. (Deutsch, Coleman, \& Marcus, 2006) It is also widely accepted that the problems in conflicts mostly have been solved by the intercultural exploration when participants change their mindset about each culture.

Lederach (1995) pointed out that it is quite understandable situation or medium in peace process when people focus and respect to their cultural inheritance and process. (Lederach, 1995) Moreover, Appleby (2000) mentioned cultural and religious heritages as resources for applying in complicated uses of practices, values and norms in multidimensional ways of peace process. (Appleby, 2000) It is noticeable that clarification and explanation about cultural assumptions and historical experiences are so important in discussing and talking about the practices for some specific contents in peace and peacebuilding process. Generally, Coward and Smith (2004) regarded religious and cultural identities as the main points in the system of resolving deep-rooted long conflict and so it is significantly essential to figure out the genuine of cultural values, norms and beliefs in peacebuilding. (Coward \& Smith, 2004)

\subsection{Cultural Communication in Conflict Resolution and Peace}

Likewise, the culture is so important in the conflicts and peace process, communication is also the fundamental thing 
for understanding and knowing conflicts and peace process. (Bolton, 1986) According to Kriesberg (1998), anger, gender and culture of individuals can have impacts on the human's emotional mindset of conflict and also they are good approaches for negotiation in peace process. (Kriesberg, 1998) It is natural that all conflicts with strong ideologies and hatred are influenced by the interpersonal and cultural shifts which could lead to strong social conflict. (Ryan, 2013) Pederson (2004) also pointed out that culture has various powers that it can be used as a negative tool for making individuals apart and also it is useful as a bridge between parties for achieving mutual understanding through intercultural ideologies. (Pedersen, 2004)

On the other hand, Samovar, Porter and Jain (1981) reflected that culture is the basic fundamental thing for communication, so communication practices might be different when cultures are different. (Samovar, Porter, \& Jain, 1981) Moreover, Dodd (1981) also argued that there is always communication implication in every cultural differences for the whole intercultural practices. (Dodd, 1981) Gudykunst and Kim (1984), again mentioned that the significance of intercultural communication is shaped by the communicators from different cultural backgrounds and practices. (Gudykunst \& Kim, 1984) According to Samovar and Porter (1991), culture is obviously important for the improvement of individuals' social practices and communication behavior. For example; it sometimes occurs that the messages are probably changed when they are sent to another culture. (Samovar \& Porter, 1991)

Hall defines communication as the heart of all intercultural interaction. He argued that culture is a kind of communication and it might also be seen as a continuous process of communicating and reinforcing group norms. Under the term of communication, transmitting messages (verbally or non-verbally) to another person, who decodes (that is translates) these messages by giving them meaning. For Scarbaugh (1984), the intercultural communication mostly analyze about the cultural factors which lead to communication (Scarbaugh, 1984) and however, Cushner and Brislin (1996) only focus on the work concerning the preparation to face the cultural difference and the upcoming problems by the culture difference such as culture shock, stereotyping, conflict, perceptual and behavioural differences. (Cushner \& Brislin, 1996)

Gudykunst (2003) stated that intercultural can be seen when a person from one culture sends a message to a person from another. On the other hand, there might have problems and conflicts when the person from the second culture does not receive the sender's intended message. In that case, intercultural communication occurs because of the differences between the sender's and the receiver's cultures.

Atwood mentioned three facts which he thought intercultural communication can be theorized openly in its development. The first one is that some researches in intercultural communication are about the interpersonal communication and such kind of analysis and researches are lack of broader generalizable insights. (Atwood, 1984) Therefore, according to him, those insights might encourage to the broader perspectives of social, cultural and communication procedures or frames for the people in their learning. Secondly, he stated that intercultural communication is a kind of open and direct link between homogeneity and heterogeneity in both culture and communication processes, so the people would communicate at different levels even in unique cultural groups. Moreover, the third facts by Atwood concerning intercultural communication is that the researches on intercultural communication sometimes determine about the culture perspectives. Therefore, he pointed out the fact, "communication determines culture" as a considerable dimension.

Hilton (2003) stated that intercultural communication continually shows the depths of understanding and misunderstanding caused by perception, interpretation, and evaluation of the sender of a message that comes from one culture and the receiver from another culture. According to Gudykunst and Kim (2003), there might be misunderstandings concerning meanings in being transmitted in normal communication between individuals, primarily because of the ambiguity in the spoken language. Quappe and Cantatore (2007) said that that kind of ambiguity might often leads to misunderstandings and misinterpretations.

Farrands (1996) stated as;

"individual inner feelings are surrounded by a social and economic context.... Questions of identity cannot be handled only by looking at the level of the individual person. They are social, economic, political and cultural questions... this psychological framework is framed socially, culturally and economically. Both as individuals and as members of groups with a position in power hierarchies and interests, we are in touch with the sources of our identity....."

Farrands (1996) mentioned as above to suggest that the communication study should be linked with the situated social practices. According to Giddens (1993), such kind of situation is called as the situated character of action which are based on the concepts of social experiences. (Giddens, 1993) On the other hand, Ang (1994) referred communication as "a social practice of meaning production, circulation and exchange" which people live in their social community. (Ang, 1994) However, Habermas (1994) mentioned communication as "lifeworld" which are the links 
between culture, society and individual person. Moreover, he added that in daily communication, persons have to deal with each and every individual in the attitude of them. (Habermas, 1994)

Intercultural communication defines a kind of communication between people who have differences in many sectors such as gender, sexual orientation, living standard, nationality, ethnicity, race, religion, age and so on. Intercultural communication can also be regarded as efforts in exchanging, negotiating and mediating cultural differences in ways of language, gestures and body language. It is so obvious that intercultural communication is much more effective if both partners have sense of each other's own cultural system.

Harrison and Huntington (2000) mentioned that culture plays as the important role in conflict resolution and he stated as;

"The role of cultural values and attitudes as obstacles to or facilitators of progress has been largely ignored by governments and aid agencies. Integrating value and attitude change into development policies, planning and programming is, I believe, a promising way to assure that, in the next fifty years, the world does not relive the poverty and injustice that most poor countries and underachieving ethnic groups, have been mired in during the past half century." (Harrison \& Huntington, 2000)

A range or measures targeted to reduce the risk of lapsing or relapsing into conflict by strengthening national capacities at all levels for conflict management, and to lay the foundation for sustainable peace and development. Peacebuilding strategies must be coherent and tailored to the specific needs of the country concerned, based on national ownership and should comprise a carefully prioritized, sequenced, and relatively narrow set of activities aimed at achieving the above objectives. Peace cannot be always recognized as the absence of war because the real meaning of peace is having strong sense of human rights, social justice and human security throughout the whole process to peace. Moreover, the most important task in peacebuilding and conflict resolution is figuring out the mobilization of the people and resources in the way of transforming the unfair procedures and relationships in the past. (Senehi, 2006)

According to MacGinty (2008), culture is always in its key role by helping the transformation of traditional methods of peacemaking in peacebuilding process based on international standard. (Ginty, 2006) When there is more cultural differences in the community, there are more chances to have conflicts due to the difficulty of communication between people in the community. Rabie (1994) explained about the culture diversity and conflict as;

"Diverse human interests and needs, largely incompatible religious social beliefs and competing individual and group goals cause conflict to arise and prevail." (Rabie, 1994)

As the societies are more homogeneous, the conception about how to interpret culture in communication is based on the significant remarks such as skin color, religion, nationality, gender or ethnicity. (Avruch \& Black, 1990) According to Shils (1957), the conceptions in the society such as language, ethnicity, customs and traditions, religion, race and so on lead to primordial sentiments which are the most fundamental connections in the society. (Shils, 1957) As the different perceptions of culture occur to the misunderstanding between people in the society, Glen (1962) introduced the term "diplomatic culture" in the research about intercultural communications. (Glen, 1962) According to Hoffman (1984), modesty and graciousness are the most fundamental factors in intercultural communication which encourage well in peacebuilding. (Hoffman, 1984) Burton and Sandole (1986) stated that "culturally involved ways which are needed to express openly" have impact on long-term and deep-rooted conflicts. (Burton \& Sandole, 1986) Intercultural communication always applies the various ideologies of culture for developing new approaches and figuring out the new solution for conflicts. Such kind of intercultural conflicts mostly can be found in international conditions, and also in some heterogeneous nations with diverse ethnic and religious groups in the world. (Deutsch, Coleman, \& Marcus, 2006)

In most of the conflict, the identity issues are always serious problems to resolve and also the basis common ground especially cultural identity. Concerning the multicultural identity, there are three to five stages of cultural identification for individuals in changing the experience. Connerly and Pederson (2005) explained those five stages as;

"First, there is an identification with the dominant culture in a preen counter, conformity, or traditional stage. Second, there is an awakening to the impact racism (including sexism, ageism and so on) in a transitional encounter or dissonant stage, often involving anger toward the dominant culture by minorities. Third, there is an identification with one's own ethnic group. Fourth, there is an internalization and integration of both culture." (Connerly \& Pedersen, 2005)

Cultural is always defined as the indirect way of influence on the theory of multicultural conflict resolution. Such kind of conditions in the conflicts are mostly complicated with mutual work and consideration on each other between parties in conflicts and so on. (Deutsch, Coleman, \& Marcus, 2006) For a peace negotiator, it is necessary to understand the culture and history of the other's and also try to tie good and active relationship with the opponents. 
Those things obviously lead to the significant appearance of conflict resolution between the parties in conflict. (Cohen, 1991) According to Dodd (1981), intercultural communication is the basic foundation for all interaction in the community. Moreover, the socio-cultural perspectives should be focused for the development of the understanding of the communication in the multicultural society if the intercultural communication is a specific type in the multicultural society. (Dodd, 1981)

Hannerz (1992) argued that the building of communication models in specific way might be developed for the ways of cooperation the connection between individual behavior in communication and present social experience in the society because individual is the recipient of the culture in the multicultural society and also they are the ones who are involving practically, intellectually and emotionally in the society. Here, not only Giddens but also Hannerz developed problems to support an approach for locating intercultural communication in a multicultural col

\section{Research Method and Data Collection}

For collecting the required data, facts and opinions, the researcher mainly use qualitative research based on the in-depth interview. According to Kvale (1983), interviews are defined as the effective tool which are used in qualitative research method for collecting the descriptions of the interviewees and participants by interpretation their comments and words of the participated interviewees. (Kvale, 1983) In interview methods, face-to-face, on telephone and lately on the internet which are via email, some messaging application and so on are mainly used as the effective tools. Opdenakker (2008) defined cyberspace which means that using internet instead of face-to-face interviews as "synchronous communication" while face-to-face interviews are regarded as the traditional ways of making in real place. (Opdenakker, 2006)

For the specific data, the researcher had a group discussion with the ethnic people which are from different social backgrounds in two townships where most of the residents are ethnic people. The researcher made group discussion with 5 people who are businessmen, community leaders and religious leaders in those regions. Moreover, the other group discussion is with 6 people who are retired government officers, politicians, representatives of national assembly for constitution (1990) and so on. The discussions are mainly focused about the role of culture and how culture supports better communication not only in minority groups but also with majority people in the community.

\section{Analysis}

Galtung stated that problems concerning culture, human needs and fault-lines of the human condition have turned into the peace discussion. (Galtung, 1990) For analyzing the culture communication, there are so many factors to evaluate the impact of culture communication. Then, the analysis part is based on the significant 3 factors which are language factor, religion factor and ethnic identity factor. The research result and analysis are measured according to the data from the in-depth interview with the ethnic people in two regions.

\subsection{Culture communication as Ethnic Identity}

Ethnicity identity is another major force that may contribute to the effectiveness of communication. Due to the different abilities to understand and gain information of people, there are gaps in how different person understands the same piece of information. And that created the two groups of people: the haves and the have-nots. (Connerly \& Pedersen, 2005)

For the case of ethnic identity, the ethnic minority people always have had the feelings of being discriminated by the majority people. Therefore, they always claim that they just would like to have equality in identity and rights. On the other hand, they also demand for the self-determination for their community and regions wishing for a better situation about identity and ethnic rights.

"Whoever the king is, we, ethnic people will surely feel satisfied when the king gives us equality and peaceful lives. We just want to have self-administration in our regions. We want to have classification based on nationality and ethnicity." (Group Discussion 2)

In interview, the participants added the historical events about their freedom of expression and rights in the country. The participated ethnic people used the term "burmanization" for showing the inequality between majority Burmese groups and other minority ethnic people.

"As far as I learnt from the ancestors, there is "burmanization" in some cases. We suffered a lot concerning political rights. There were some places where we could discuss about ethnic rights and affairs before 1974. But, after that, we totally lost every right." (Group Discussion 2)

"We assumed that current ethnic armed groups are small organizations to fight the inequality in ethnic affairs back. Some ethnic people are holding weapons for their ethnic pride. For example; Palaung ethnic group gets support from the Paluang people which are staying in China boarder." (Group 


\section{Discussion 2)}

According to the participants from group discussion 2, there have been ethnic revolution groups or ethnic armed groups because they want to have equality in ethnic affairs. Moreover, they claim that some ethnic armed groups could protect their own ethnic people.

"Before, we experienced suppression a lot in verbal harassment on Karen people. So, we felt so sad about it. As long as that kind of harassment exist, it will be so difficult to build peace. We asked for our rights peacefully in the history but we didn't get our rights. So, we chose the weapons." (Group Discussion 2)

Identity is so important for human being that it is also a definition of being recognized for individual in the community. Therefore, the ethnic people always demand for the freedom of ethnic identity in the community as the political right. Due to participants from group discussion 2, it is so obvious that the ethnic people chose weapons or follow the armed revolution for their ethnic rights and identity. Therefore, it could be analyzed that ethnic identity can be applied as a better communication tool for conflict resolution.

\subsection{Culture Communication as Language and Literature}

Language and literature are probably the most important elements of communication. Language is the mean of communication. Moreover, Samovar, Porter \& McDaniel mentioned that "Language is the medium through which a culture expresses its world view". Language needs to be learned and used effectively in order to achieve successful intercultural communication. And if language is a tool then culture may be considered as the environment that has all the effects on language. Because of that, culture is, in many circumstances, what defines the meaning of language. (Samovar, Porter, \& McDaniel, 2009)

In Myanmar, the languages and literatures are different depending on the ethnic groups, so it can be said that there is a huge diversity in the language and literature sector. On the one hand, the government regards "Burmese" which is the language of major ethnic group as the official language of the country. That's why, it can be seen that the ethnic people in some remoted area have been in trouble in learning due to the language barrier.

"They use Burmese language for teaching because it is official language in the country. Actually, in schools, we have to learn with Burmese language. And, we use our ethnic language at home or in church. So, I am sometimes unhappy that I cannot speak Burmese so well. Even I feel depressed when I don't know how to speak formal Burmese language beautifully. Now, my Burmese is just under ordinary level." (Group Discussion 1)

Although most ethnic people have been trying so hard to learn Burmese language because it is the official language of the country, they still have some language barriers. Moreover, the language and literature are the symbol of the one's culture and tradition, so the ethnic people always try to promote their language and literature. Apart from the support by their own self, ethnic people surely would like to get encouragement or support from the government, but they have never got the support from the government.

"Now, there are some Literature and Culture Organization in some ethnic groups. They are also registered according to government's procedure. But, there is no budget for that organization by the government. We have to work ourselves with our own support." (Group Discussion 1)

There is one more problem concerning language barrier for ethnic people in ethnic regions. It is about education system which is teaching and learning in schools. The ethnic teachers have to use unfamiliar language as medium language for teaching in other regions and also the children from ethnic regions are trying so hard to learn Burmese language first before the formal education as well. Therefore, the process is like a two-steps process in teaching-learning system although direct process is the best for all education.

"The teachers were shuffled to some other regions. For example; Karen teachers were assigned to Burmese regions and Burmese teachers were appointed to Karen regions. Because of the language barriers, the education standard in ethnic region was low. Now, we need to fight for our rights and our living standard." (Group Discussion 2)

It becomes essential to consider about the role of language in conflict resolution because language and literature are the best communication tool themselves originally. Due to the participants' discussion, it is obviously seen that the development of the language and literature sector is one of the best culture communication tools for ethnic rights and even conflict resolution.

\subsection{Culture Communication as Religion}

Not to mention the fact that religion plays an important role in cultural differences. Religion identity is sometimes 
improving communication where it shares similar interests. It is also the main cause of conflict when its interest is not satisfied by another religion. (Rabie, 1994)

Whenever we discuss about the culture, religion is the necessary topic to be discussed because every person value and rely on their respective religion in their society.

"Before, we didn't have real freedom. We had to get permission when we wanted to celebrate religious ceremonies. If we were absent to apply the permission for that, we would have been punished. We even had to inform them about the procedures of ceremony, the number of guests and so on. Sometimes, we were inquired by the army. Now, there is no tension and pressure anymore, so the tourism industry has improved a lot." (Group Discussion 1)

In Myanmar, the majority people are Buddhists and there are also Christians, Muslim, Hindus and other believers. Most ethnic people in mountain area are Christians and there are also some other ethnic Buddhists. Ethnic Christians always claims about the discrimination on the religion in the country. According to the participants from group discussion 1, the ethnic Christians had suffered suppressions and restrictions concerning religion throughout the military regime before 2011. However, there is no such a case anymore because the country's government has become democratic government.

"If a person is Christian, he or she cannot get promotion. As long as they use discrimination a lot, there will no longer be peace. Though such kind of problems become less these days, there is still some." (Group Discussion 2)

When the participants discussed about the job opportunities and the situation of ethnic Christians in the country with the majority group, they mentioned about the discriminations which they had faced before in work field.

Although there are a wide range of arguments and various opinions on the relationship between religion, culture, peace and conflict, it can be seen that there is also relationship between the role of religion and conflict resolution. (Olajide $\&$ Philip, 2017) Nevertheless, Huntington (1996) argued in Olajide (2017) and Phillip (2017) that religion and culture is central, perhaps the central force in the modern world that motivates and mobilize people. Marty (2000) believed that religion and culture are the key roles in building community while tempting to myth and symbol through customs and traditions and the adhering behavior. (Olajide \& Philip, 2017)

\section{Conclusion}

According to Gudykunst (2003), the term "culture" is such kind of knowledge of a specific group of people ways of life which include language, religion, social habits, music and arts. (Gudykunst, 2003) Therefore, challenges appear as a consequence differences and misunderstanding when two or more culture coincide in a community or society or a nation. In Myanmar's roots of ethnic conflicts in the borderlands, some scholars and researchers argued that ethnic conflicts can be seen in political manipulation of ethnic and religious identities, the competition and conflict for political power by the ethnic communities.

Moreover, due to many reasons, understanding cultural communication in peacebuilding sector becomes obligatory for every nations' government. The study aims to discover the important role of cultural communication and find out the ways for addressing grievances of the local people or victims in the conflict area in Myanmar who are suffering and fleeing from their native places because of conflicts. According to the participants from group discussion, they always demand for the equality for ethnic rights and identities. Therefore, let's explore about what they really want or what are included in ethnic rights.

Based on the result come out from the in-depth discussions in two regions with over 10 people, all they are wishing for is access to their ethnic rights and equality. In most cases, the participants mentioned about the problems concerning language, religion and hidden identities. Therefore, the problems are mainly based on the culture-related cased in the community with the majority groups.

Since from the previous government time, the conflict resolution and peace process have been established by implementing Myanmar Peace Centre (MPC) with retired military personnel, ethnic representatives and communication professionals for peace process. After 2015 election, the new NLD government changed the system of MPC into National Reconciliation and Peace Centre (NRPC) with peace scholars, retired and current government officers, representatives from military and ethnic armed groups. However, the whole process does not move forward although the time passes by.

It is significant that conflict resolution is related with the military case, however, the whole process of conflict resolution and peace totally does not depend on the military sector. As long as the process is necessary to depend on the military sector, it is not real peace and conflict resolution and it is not an absolute and long-term peace process. Therefore, the government needs to find the better solution or alternative way to approach the conflict resolution and 
peace process of Myanmar. In that case, based on the participants' comments and opinion about the ethnic conflict and peace, the study recommends the huge support by the government for ethnic culture and tradition as a culture communication tool is a better way to approach to the sensitive conflict resolution and peace process of Myanmar. Throughout the time, ethnic culture and tradition has been ignored and hid behind the public. Therefore, it is time to promote and encourage the ethnic culture as an effective communication tool to bridge the gap between majority people and ethnic minority people in the country. Moreover, culture communication could be also applied as the driving factor for resolving the conflicts in multiethnic states.

\section{References}

Ang, I. (1994). In the Realm of Uncertainity: The Global Village and Capitalist Postmodernity. In D. Crowley, \& D. Mitchell, Communication Theory Today. Cambridge: Polity Press.

Appleby, R. S. (2000). The Ambivalence of the Sacred: Religion, Violence, and Reconciliation. Lanham: Rowman and Littlefield Publishers.

Atwood, R. (1984). Critical perspectives on the state of intercultural communication research. Progress in Communication Sciences, 67-90.

Avruch, K., \& Black, P. W. (1990). Ideas of Human Nature in Contemporary Conflict Resolution Theory. Negotiation Journal, 16(1), 221-228. https://doi.org/10.1111/j.1571-9979.1990.tb00575.x

Bolton, R. (1986). People Skills: How to Assert Yourself, Listen to Others and Resolve Conflicts. New York: Simon and Schuster.

Burton, J. W., \& Sandole, D. J. (1986). Generic Theory: The Basis of Conflict Resolution. Negotiation Journal, 2(3), 333-345. https://doi.org/10.1111/j.1571-9979.1986.tb00373.x

Cohen, R. (1991). Negotiating Across Cultures. Washington: Institute of Peace.

Connerly, M. L., \& Pedersen, P. B. (2005). Leadership in a Diverse and Multicultural Environment: Developing Awareness, Knowledgem and Skills. California: Sage. https://doi.org/10.4135/9781483328966

Coward, H., \& Smith, G. S. (2004). Relgion and Peacebuilding. New York, United States of America: State University of New York Press.

Cushner, K., \& Brislin, R. (1996). Intercultural Interactions. A Practical Guide. Thousand Oaks: Sage Publications.

Deutsch, M., Coleman, P. T., \& Marcus, E. C. (2006). The Handbook of Conflict Resolution: Theory and Practice. San Francisco: Jossey-Bass.

Dodd, C. (1981). Dynamics of Intercultural Communication. Dubuque: Wm C Brown Publishers.

Galtung, J. (1990). Cultural Violence. Journal of Peace Research, 27(3). https://doi.org/10.1177/0022343390027003005

Giddens, A. (1993). Sociology. Cambridge: Polity Press.

Ginty, R. M. (2006). No War, No Peace: The Rejuvenation of Stalled Peace Processes and Peace Accords. New York: Palgrave Macmillan. https://doi.org/10.1057/9780230625686

Glen, E. S. (1962). Semantic Difficulties in International Communication. In S. I. Hayakawa, The Use and Misuse of Language. New York: Harper Brothers.

Gudykunst, W. B. (2003). Cross-Cultural and Intercultural Communication. SAGE.

Gudykunst, W., \& Kim, Y. (1984). Communicating With Strangers. An Approach to Intercultural Communication. New York: Random House.

Habermas, J. (1994). The Theory of Communicative Action. Boston: Veacon Press.

Hall, E. T. (1976). Beyond Culture. New York: Anchor Books.

Harrison, L. E., \& Huntington, S. P. (2000). Culture Matters. New York: Basic Books.

Hoffman, S. (1984). Detente. In J. S. Nye, The making of America's Soviet Policy: New Haven. Yale University Press.

Kriesberg, L. (1998). Constructive Conflicts: From Escalation to Resolution. Lanham: Rowman \& Littlefield.

Kvale, S. (1983). The qualitative research interview: A phenomenological and hermeneutical mode of understanding. Journal of Phenomenological Psychology, 171-196. https://doi.org/10.1163/156916283X00090

Lederach, J. P. (1995). Preparing for peace : conflict transformation across cultures. New York: Syracuse University Press. 
Olajide, A., \& Philip, O. (2017). Cross Cultual Communication and Peace building in Kaduna State, Nigeria. International Journal of Arts, Humanities and Management Studies, 3(1).

Opdenakker, R. (2006, 03 13). Advantages and disadvantages of four interview techniques in qualitative research. Forum Qualitative Sozialforschung/Forum: Qualitative Social, 7(4). Retrieved from http://www.qualitative-research.net/index.php/fqs/article/view/175

Pedersen, P. B. (2004). 110 Experiences for Multicultural Learning. Washington, US: American Psycholocial Association.

Rabie, M. (1994). Conflict Resolution and Ethnicity. Westport: Praeger.

Ryan, S. (2013). The Transformation of Violent Intercommunal Conflict. Hampshire, England: Ashgate Publishing, Ltd.

Samovar, L., \& Porter, R. (1991). Intercultural Communication: A Reader. Belmont: Wadsworth.

Samovar, L., Porter, R., \& Jain, N. (1981). Understanding Intercultural Communication. Belmont: Wadsworth Publishing Company.

Samovar, L., Porter, R., \& McDaniel, E. R. (2009). Communication between cultures. Boston, USA: Wadsworth.

Scarbaugh, L. (1984). An Overview of Selected Approaches. In W. Gudykunst, \& Y. Kim, Methods for Intercultural Communication Research. Beverly Hills: Sage Publications.

Senehi, J. (2006). From Violence Toward Peace: The Role of Storytelling for Youth Healing and Political Empowerment After Conflict. In S. McEvoy-Levy, Troublemakers or peacemakers? : youth and post-accord peace building. London, England: Notre Dame, Ind. : University of Notre Dame Press.

Shils, E. (1957). Primordial, Personal, Sacred and Civil Ties . The British Journal of Sociology, 8, 130-145. https://doi.org/10.2307/587365

Smith, M., \& Ekeh, C. (2007, October). Minorities in Burma. London, UK: Minority rights group international.

Tucker, S. (2001). Burma: The curse of independence. 8-9.

\section{Copyrights}

Copyright for this article is retained by the author(s), with first publication rights granted to the journal.

This is an open-access article distributed under the terms and conditions of the Creative Commons Attribution license which permits unrestricted use, distribution, and reproduction in any medium, provided the original work is properly cited. 